\title{
A Botanical Profile and Phytochemical Evaluation of Leaf, Stem and Root of Egyptian Lycopersicon esculentum Miller
}

\author{
Fify I. Fathy, Marawan M. Shabana, Hoda A. Mansour, Manal M. Sabry*
}

Fify I. Fathy, Marawan M. Shabana, Hoda A. Mansour, Manal M. Sabry*

Department of Pharmacognosy, Faculty of Pharmacy, Cairo University, Cairo, 11562, EGYPT.

\section{Correspondence}

\section{Manal M. Sabry}

Department of Pharmacognosy, Faculty of Pharmacy, Cairo University, Cairo, 11562, EGYPT.

E-mail: manal.sabry@pharma.cu.edu.eg History

- Submission Date: 18-04-2021;

- Review completed: 24-05-2021;

- Accepted Date: 09-06-2021.

DOI : 10.5530/pj.2021.13.132

Article Available online

http://www.phcogj.com/v13/i4

Copyright

(c) 2021 Phcogi.Com. This is an openaccess article distributed under the terms of the Creative Commons Attribution 4.0 International license.

\begin{abstract}
Background: Tomato plant (Lycopersicon esculentum Miller, Family Solanaceae) is one of the most important vegetables worldwide for its edible fruit. Other plant organs (leaf, stem, and root) are discarded after harvesting. Reports showed that these worthless plant organs are rich untapped sources of biologically active constituents, which encourage us to do further investigation. However, lack of standardization for this plant represented a problem facing their use in medicine. Objective: The objective of the current work is to establish a botanical profile for the leaf, stem, and root, to perform a phytochemical investigation including estimation of the total phenolics and flavonoids content, as well as identification of isolated pure compounds from the highest yield organ. Methods: Samples of each organ have been examined macroscopically and microscopically. A phytochemical investigation including successive extraction, estimation of the total phenolics and flavonoids content were carried out. The different fractions of the leaf, having the highest yield, were subjected to phytochemical investigation using successive columns of silica gel and sephadex. Results: Colorimetric estimation of the total phenolics and flavonoids content showed that the leaf has the highest values $(84.29 \pm 1.50,50.49 \pm 0.26)$ followed by the stem $(50.94 \pm 0.33$, $9.10 \pm 0.14)$ then the root $(40.71 \pm 0.07,1.32 \pm 0.01)$, respectively. Six known compounds namely: apo$\beta$-carotenol, $\beta$-sitosterol from the $n$-hexane fraction, protocatechuic acid, stigmasterol 3-O- $\beta$-D- glucoside from the ethyl acetate fraction, quercetin and rutin from the $n$-butanol fraction were isolated and their structure elucidation was confirmed by NMR spectroscopy. Conclusion: This study could provide an authenticated data base for this Lycopersicon species.

Key words: Pharmacognostical study, Lycopersicon esculentum Miller, Macro- and micromorphology, Total phenolics and flavonoids content.
\end{abstract}

\section{INTRODUCTION}

Lycopersicon esculentum Miller (syn; Solanum lycopersicum L, Lycopersicon lycopersicum L., Family Solanaceae), is one of the main vegetables in USA, Europe, China, Turkey, and Egypt. ${ }^{1,2}$ The fruit has a good nutritive value being rich in vitamins ( $\mathrm{A}, \mathrm{B}_{1}, \mathrm{~B}_{2}, \mathrm{~B}_{3}, \mathrm{~B}_{5}, \mathrm{~B}_{6}$, and $\left.\mathrm{C}\right)$, lycopene, organic acids (citric and maleic acids), amino acids (tryptophan, threonine, leucine, isoleucine, lysine, methionine, histidine, phenylalanine and valine) and minerals such as sodium, potassium, calcium, magnesium, zinc, phosphorus and iron..$^{2-6}$

Among the several reviews on the plant growing abroad, ${ }^{6-12}$ few studies focused on the plant waste (leaf, stem, and root) being discarded after harvesting. ${ }^{13-15}$ Reports showed that these worthless plant organs are rich untapped sources of biologically active constituents belonging to different chemical classes viz.; steroidal alkaloids, flavonoids and other phenolics, ${ }^{11}$ which encourage us to do further investigation. Botanical characterization is lacking for these organs. A little information on the chemical composition and the biological activities of the Egyptian plant are available. ${ }^{16-19}$

Lack of quality control for raw materials represents an obstacle behind the acceptance of alternative medicine in developed countries. Accordingly, this study was designed to establish a macro- and micromorphological characterization or the leaf, stem, and root to help in the authentication of the plant. Moreover, successive extraction of each of these organs, phytochemical investigation including screening, estimation of the total phenolics and flavonoids contents in addition to identification of isolated pure compounds from the highest yield organ were carried out.

\section{MATERIALS AND METHODS}

\section{Plant material}

The seeds of Lycopersicon esculentum Miller were purchased from Agricultural Research Center, Dokki, Giza, Egypt and cultivated in a private garden in Menoufia, Egypt. Samples of the plant were collected after harvesting of the fruit (August, 20162017) and was kindly identified and authenticated by Dr Abdel-Halim Abdel-Motagaly Mohamed, Senior Researcher in Department of Flora \& Phyto-taxonomy Research, Agriculture Museum, Dokki, Giza, Egypt. A voucher specimen (No. 05-11-2019) was kept at the Museum of the Pharmacognosy Department, Faculty of Pharmacy, Cairo University, Egypt.

\section{Botanical study}

Microscopical examinations were performed on preserved samples of the leaf, stem, and root in 70 $\%$ alcohol containing $5 \%$ glycerin. Cross-sections and powdered air-dried samples (No.36 were photographed using microscope with Sony Digital camera (Leica microsystems, Germany). 


\section{PHYTOCHEMICAL STUDY}

\section{Preliminary phytochemical screening}

Air-dried powdered samples of the leaf, stem, and root of Lycopersicon esculentum Miller were separately tested for the presence of carbohydrates and/or glycosides, sterols and / or triterpenes, alkaloid and/or nitrogenous compounds, flavonoids, tannins, cardiac glycosides and saponins. ${ }^{20}$

\section{Extraction and fractionation}

Air-dried powdered samples of Lycopersicon esculentum Miller leaf, stem, and root (1130 g, $1561.7 \mathrm{~g}$ and $150 \mathrm{~g}$, respectively) were separately extracted by cold percolation in ethanol $70 \%$ till exhaustion. The collected ethanolic extract for each organ was separately evaporated under reduced pressure at a temperature not exceeding $40^{\circ} \mathrm{C}$. Samples of the ethanolic residues $(136.3 \mathrm{~g}, 150 \mathrm{~g}$ and $5 \mathrm{~g}$ for leaf, stem, and root, respectively) were separately suspended in $200 \mathrm{~mL}$ of distilled water, while the root was suspended in $20 \mathrm{~mL}$ of distilled water and successively partitioned with solvents of increasing polarities $n$-hexane, methylene chloride, ethyl acetate and $n$-butanol (saturated with water) till exhaustion. The fractions were concentrated to dryness under reduced pressure at a temperature not exceeding $40^{\circ} \mathrm{C}$.

\section{Estimation of total phenolics and flavonoids content}

The total phenolics content of the $70 \%$ ethanolic extracts of the leaf, stem and root were analyzed using a Shimadzu Spectrophotometer (UV-1650PC) ${ }^{21}$ A stock solution $(1 \mathrm{mg} / \mathrm{ml})$ was separately prepared by dissolving $10 \mathrm{mg}$ of each ethanolic extract in $10 \mathrm{ml}$ of $50 \%$ methanol. Serial dilution with methanol was carried out to yield $5-100 \mu \mathrm{g} / \mathrm{mL}$. An aliquot of $100 \mu \mathrm{L}$ was mixed with $500 \mu \mathrm{L}$ Folin-Ciocalteu reagent (freshly diluted $1 / 10$ with distilled water) and $1.5 \mathrm{~mL}$ of $\mathrm{Na}_{2} \mathrm{CO}_{3}(20 \%$ ), incubated at room temperature in the dark for $30 \mathrm{~min}$ with occasional shaking and the absorbance of the obtained color was measured at $\lambda_{\max }$ $765 \mathrm{~nm}$. The total phenolics content of each organ was expressed in $\mu \mathrm{g}$ of gallic acid equivalents ( $\mu \mathrm{g} \mathrm{GAE} / \mathrm{mg}$ of each dried extract).

The total flavonoids content was determined by aluminum chloride method $^{22}$. Stock solutions $(1 \mathrm{mg} / \mathrm{mL})$ were separately prepared by dissolving $10 \mathrm{mg}$ of the ethanolic extract in $10 \mathrm{~mL}$ of $95 \%$ ethanol and serially diluted with methanol to yield $5-100 \mu \mathrm{g} / \mathrm{mL}$. An aliquot $(0.8 \mathrm{~mL})$ of each ethanolic extract $(1 \mathrm{mg} / \mathrm{mL})$ was mixed with $1.5 \mathrm{~mL}$ methanol, $0.1 \mathrm{~mL}$ aluminum chloride, $0.1 \mathrm{~mL}$ potassium acetate solution and 2.8 $\mathrm{mL}$ distilled water. The absorbance of the resulting color was measured after 30 min at $\lambda_{\text {max }} 415 \mathrm{~nm}$, the total flavonoids content was expressed as $\mu \mathrm{g}$ of quercetin equivalents ( $\mu \mathrm{g} \mathrm{QE} / \mathrm{mg}$ of dried extract).

\section{Isolation and identification of compounds}

The $n$-hexane fraction $(32 \mathrm{~g})$ of the leaf was subjected to vacuum liquid chromatography column (VLC) $(7 \times 25 \mathrm{~cm}$, silica gel H 60 (Merck), $300 \mathrm{~g}$ ). Gradient elution was performed using $n$-hexane, $n$-hexane methylene chloride mixtures. Fractions, $(100 \mathrm{~mL}$ each) were collected and monitored on TLC precoated silica gel $60 \mathrm{~F}_{254}$ plates (Fluka) using $\mathbf{S}_{1}$ (n-hexane-methylene chloride $8: 2 \mathrm{v} / \mathrm{v}$ ) as solvent system for development with $p$ - anisaldehyde as a spraying reagent. Three fractions were obtained (I-III). Fractions II (1-5\% methylene chloride in $n$-hexane) and III (20-25\% methylene chloride in $n$-hexane) were separately re-chromatographed on silica gel 60 columns using gradient elution of $n$-hexane - methylene chloride leading to the isolation of two pure compounds: compound 1 from fraction II (30 mg, yellow needle crystals, $R_{f} 0.33$ in $S_{1}$ ) and compound 2 from fraction III ( $22 \mathrm{mg}$, white needle crystals, $R_{f} 0.40$ in $S_{1}$ ).

The ethyl acetate fraction $(7.5 \mathrm{~g})$ was subjected to fractionation on VLC silica gel column $(7 \times 25 \mathrm{~cm}, 300 \mathrm{mg})$. Gradient elution was carried out using methylene chloride, methylene chloride - methanol mixtures; fractions $(100 \mathrm{~mL}$, each) were collected resulting to five main collective fractions (I-V). Fraction I (1-2\% methanol in methylene chloride) was refractionated on series of sephadex LH-20 columns (Pharmacia, Stockholm, Sweden) using methanol-water (1:1) and (1:9) as eluents leading to isolation of compound (3) (14 mg, yellow fine crystals, m.p. $198-200^{\circ} \mathrm{C}, \mathrm{R}_{\mathrm{f}} 0.5$ in $\mathrm{S}_{2}$ ). Fraction IV (8-20\% methanol in methylene chloride) was subjected to refractionation on sephadex LH-20 column using methanol-water (2:8) leading to isolation of compound (4) $(17.5$ mg white crystals, m.p. $280^{\circ} \mathrm{C}, \mathrm{R}_{\mathrm{f}} 0.9$ in $\mathrm{S}_{2}$ ) where $\mathrm{S}_{2}$, ethyl acetatemethanol-water-formic acid (100: 16.5: 13.5: $0.2 \mathrm{v} / \mathrm{v}$ ).

A portion of n-butanol fraction (12 g) was subjected to VLC chromatography, using gradient elution with ethyl acetate, ethylacetatemethanol mixtures; fractions $(200 \mathrm{~mL}$, each) were collected resulting in four main collective fractions (I-IV). Fr. I (2.14 g, 2-20\% ethyl acetate in methanol) and Fr. II (1.72 g, 21-50\% ethyl acetate in methanol) were separately chromatographed on sephadex LH-20 columns using methanol-water $(2: 8)$ as eluent, two pure compounds were obtained 5 (14mg, yellow needle crystals, m.p. $315-317^{\circ} \mathrm{C}, \mathrm{R}_{\mathrm{f}} 0.8$ in $\left.\mathrm{S}_{3}\right)$ and $6(12$ mg, yellow needle crystals, m.p. $192-195^{\circ} \mathrm{C}, \mathrm{R}_{\mathrm{f}} 0.74$ in $\mathrm{S}_{3}$ ) where $\mathrm{S}_{3}$, methylene chloride-methanol-water $(6.5: 3.5: 0.5 \mathrm{v} / \mathrm{v})$.

\section{RESULTS AND DISCUSSION}

\section{Botanical profile}

\section{Macromopohology (Figure 1)}

Lycopersicon esculentum Miller is a perennial herbaceous plant, although in its natural habitat most probably behave as annual and might die after the first growing seasons due to frost or drought. It reaches up to $1 \mathrm{~m}$ in height and about $1 \mathrm{~cm}$ in diameter at the basal part. It starts flowering after 6 weeks from cultivation and produce the first ripe fruit after 12 weeks.

\section{The stem (Figure 1a)}

The stem is weak, cylindrical, and woody. It scrambles over other plants. It measures from $80-100 \mathrm{~cm}$ in height and $1 \mathrm{~cm}$ in diameter at the basal part. It is sympodially branched with short internodes up to 1 $\mathrm{cm}$ in length. It is green in color, pubescent (hairs seen by naked eye), and hollow. It breaks with a flexible fracture It has a characteristic odor and a bitter astringent taste.

\section{The leaf (Figure 1b-d)}

The leaf is compound, imparipinnate, alternate, with 3-5 pairs of lateral leaflets (1ry leaflets). It measures $25-32 \mathrm{~cm}$ in length, petiolate and exstipulate. Smaller secondary leaflets are intersected between primary leaflets. The lateral leaflets are opposite to alternate, petiolate, ovate to lanceolate in shape with serrate to broadly dentate margins. Both surfaces are pubescent (hairs are seen by naked eye), green in color and the lower is lighter. They have reticulate-pinnate venation and the midrib is more prominent on the lower surface. They measure $3-9 \mathrm{~cm}$ in length and $0.5-6 \mathrm{~cm}$ in width. The petiole is green in color, cylindrical, pubescent (hairs are seen by naked eye), measures $3-4 \mathrm{~cm}$ in length and $0.5-1 \mathrm{~cm}$ in diameter. The smaller secondary leaflets are sessile, ovate with entire to crenate margins. The leaflets have papery texture, characteristic odor and astringent bitter taste.

\section{The inflorescence (Figure 1e,f)}

The flowers are yellow in color, arranged in a simple terminal raceme 4-7 in number. The flowers are actinomorphic, hermaphrodite and pedicellate. Pedicels measures $2-5 \mathrm{~cm}$ in length and up to $0.5 \mathrm{~cm}$ in diameter. Calyx: 5 gamosepalous fused at the basal part to form a tube ending with 5 linear teeth, green in color, densely pubescent, with acute apex. It is persistent and accrescent and developed to be strongly 
reflexed with recurved tips during the fruiting stage. Corolla: yellow in color, 5 gamopetalous, formed of triangular petal alternate with sepals. Androecium: 5 epipetalous stamens. Gynoecium: The ovary is superior, bicarpillary, bilocular and axillary placentation, usually globose or slightly elliptic, subglabrous to pubescent. The stigma is clavate and bilobed.

\section{The fruit (Figure 1g, $h$ )}

The fruit is a berry, green when immature turning red on ripening, oval, rounded, multilobed and strongly depressed, the pestil scar is irregular and blossom end shape is indented. It is up to $8 \mathrm{~cm}$ in diameter.

\section{The root (Figure $i, j$ )}

The main root is a tape root, woody, cylindrical. It measures $18-20$ $\mathrm{cm}$ in length and $1-1.5 \mathrm{~cm}$ in diameter at the widest part. The lateral rootlets are of variable length and thickness. They are dark grayishbrown in color with yellowish -white internal. The surface is rough. It breaks with a short fracture.

\section{Micromorphology}

\section{The stem (Figure 2)}

A transverse section in the stem (Figure $2 \mathrm{a}$ and $2 \mathrm{~b}$ ) is nearly circular in outline. It shows an epidermis followed by a narrow cortex, indistinct endodermis, followed by a parenchymatous pericycle. The vascular system consists of continuous ring of vascular tissue. The pith is comparatively wide and hollow showing scattered perimedullary phloem in the periphery of the pith.

The epidermis: The epidermal cells are polygonal, tangentially elongated with straight anticlinal walls, and covered with a thick smooth cuticle. Trichomes are non-glandular, numerous, uniserate, multicellular (2-4 cells), mostly long with acute tapering usually curved ends, and rounded base and covered with a striated, sometimes smooth cuticle. The stomata of anisocytic and anomocytic types are present.

The cortex consists of 5-8 rows of rounded to oval, thin-walled parenchymatous cells. It shows scattered idioblasts formed of microcrystals of calcium oxalate. The endodermis is not differentiated. The pericycle: It consists of 3-4 rows of thin walled parenchymatous cells.

The vascular system: It consists of a continuous ring of vascular tissues, traversed by uniseriate, rarely biseriate medullary rays. The phloem consists of soft tissue (phloem elements and phloem parenchyma). The

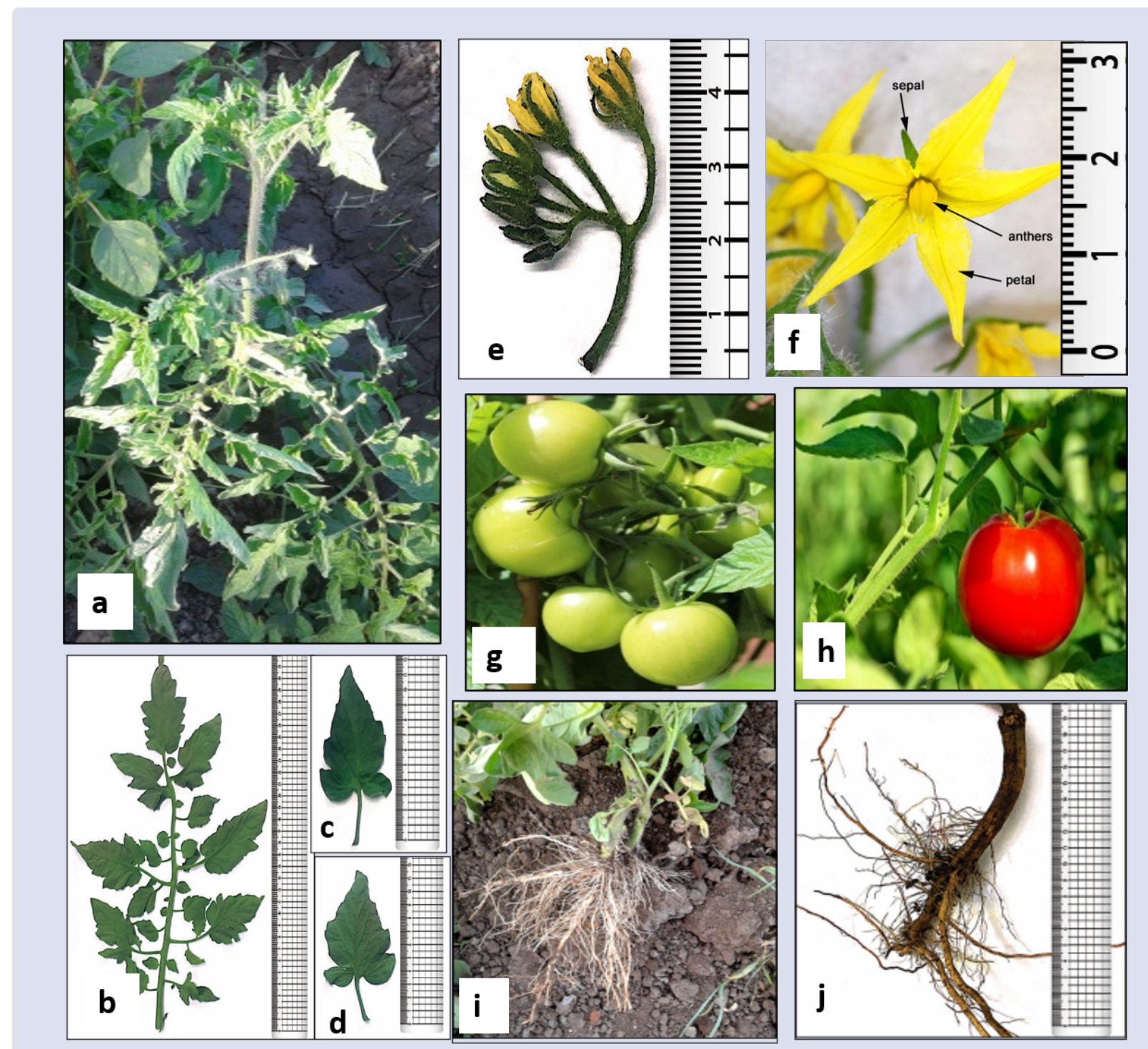

Figure 1: Macromorphology of Lycopersicon esculentum Miller; $a$, Photograph of the tomato plant; $b$, Compound leaf, $c \& d$ Upper and lower surfaces of the leaflet; $e$, inflorescence; $f$, flower; $g$, unripe fruit; $h$, ripe fruit; i \& j, root. 


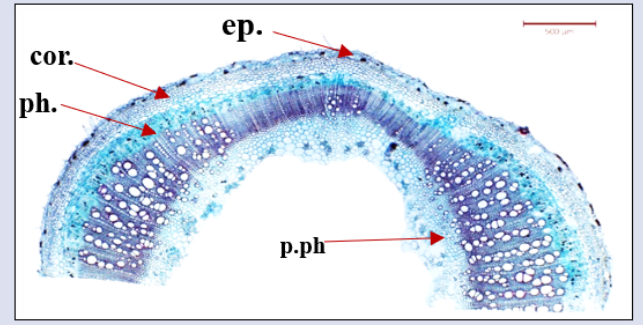

$\mathbf{a}$

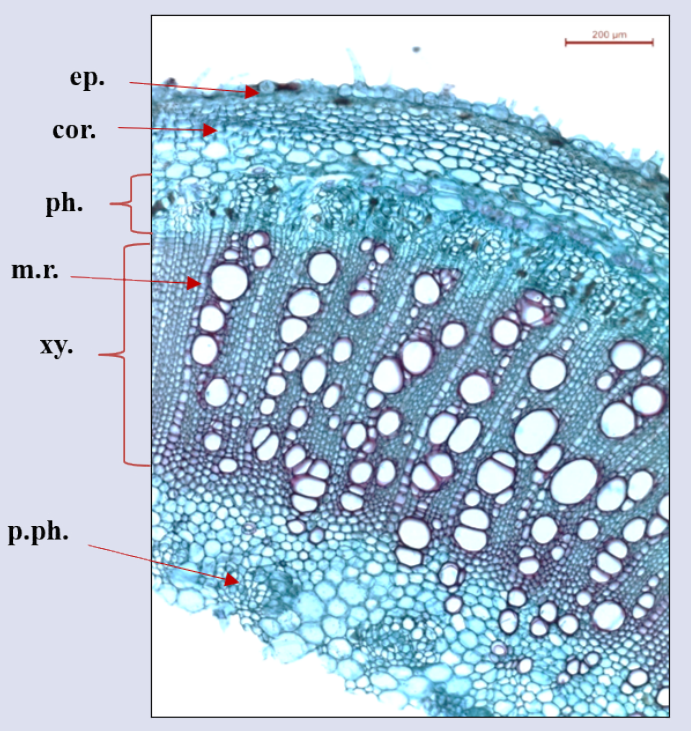

b

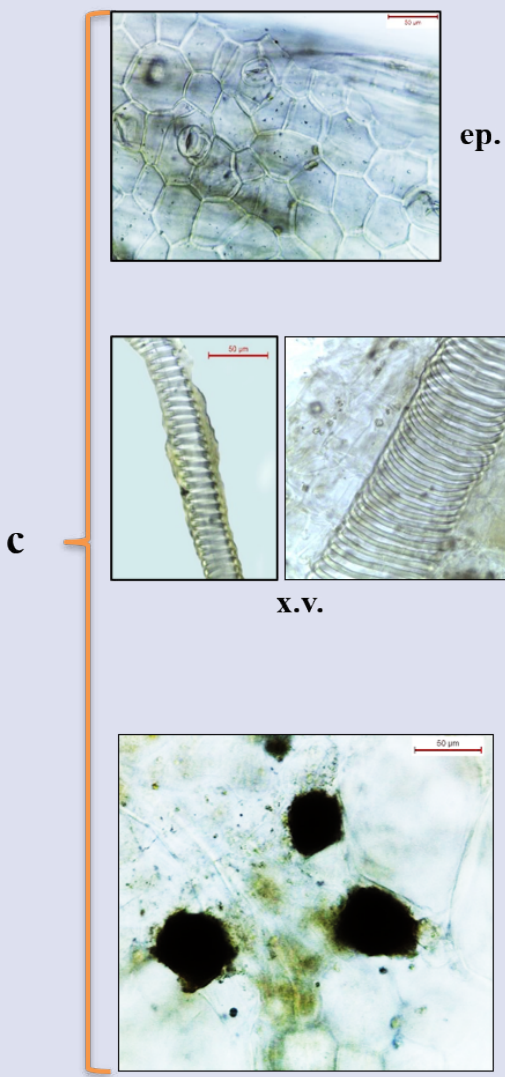

id.
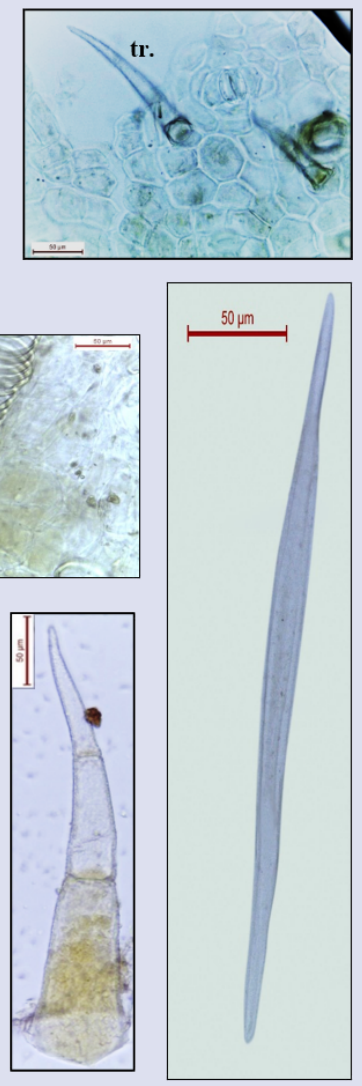

fi.

Figure 2: of the stem of Lycopersicon esculentum Miller. a, Low power of a transverse section; b, High power of a transverse section; $c$, powdered stem: cor., cortex; ep., epidermis; fi, fiber; id., idioblasts; m.r., medullary rays; n.gl.tr., non-glandular trichome; ph., phloem; $p$. ph., perimedullary phloem; x.v., xylem vessels; xy., xylem.

cambium is distinct and formed of 3 to 5 rows of cambiform cells. The xylem is lignified, formed of vessels, abundant fibers, wood parenchyma and traversed by uniserate, rarely biseriate medullary rays. The vessels are radially arranged in groups of 2-6, rarely solitary, having annular and spiral thickenings. The wood fibers are fusiform with pointed apices, thick lignified walls and showing wide lumina.

The pith is parenchymatous, formed of few rows of thin-walled cells, with narrow intercellular spaces, showing scattered idioblasts as described in the cortex. Small groups of perimedullary phloem are scattered at the periphery of the pith.

The powdered stem (Figure 2c) is green in color, has a characteristic odor and a bitter astringent taste. Microscopically it is characterized by the presence of the following fragments:

Fragments of epidermis consisting of polygonal tangentially elongated cells with straight anticlinal walls and covered with a smooth cuticle. Stomata are of anisocytic and anomocytic types. Fragments of nonglandular trichomes are uniserate, multicellular (2-4 cells) mostly long with acute tapering ends and rounded bases and covered with a striated sometimes smooth cuticle. Fragments of lignified xylem vessels with spiral and annular thickenings. Idioblasts formed of parenchymatous cells containing microcrystals of calcium oxalate are scattered in the field.

\section{The leaf (Figure 3)}

A Transverse section in the leaflet (Figure 3a) shows a narrow lamina and a biconvex midrib strongly projecting on the lower side. The epidermal cells of both surfaces are polygonal, tangentially elongated with straight anticlinal wall (in the upper) and wavy anticlinal wall (in the lower) and covered with a smooth cuticle. The stomata are of anisocytic and anomocytic types being more frequent on the lower surface. Non-glandular trichomes are present similar to those found on stem but more frequent.

The mesophyll tissue (Figure 3b): is heterogenous, dorsiventral showing one row of palisade cells abutting to the upper epidermis and being discontinuous in the midrib and neural regions. The spongy mesophyll is formed of 4-5 layers of thin-walled parenchyma.

The midrib (Figure 3c): The cortical tissue of the midrib is formed of thin-walled parenchyma cells and showed scattered idioblasts (similar to those in the stem). The vascular strand is crescent in shape. The pericycle: consists of a narrow zone of thin-walled parenchyma cells. The vascular bundle: consists of xylem towards the upper (adaxial) and phloem towards the lower (abaxial) side and traversed by uniseriate to biseriate medullary rays. The phloem is formed of soft tissue of phloem elements and phloem parenchyma. The xylem is formed of lignified elements (vessels, vessels segments and wood parenchyma). The xylem vessels are mainly with annular and spiral thickenings.

A transverse section in the petiole (Figure 3d) is nearly circular in outline with two, small projection at its lateral sides. Structurally, it similar to the midrib region of the leaf.

The powdered leaf (Figure 3e) is green in color, has a characteristic odor and an astringent bitter taste. Microscopically, it is characterized 
by the presence of fragments of the epidermal cells are polygonal having straight anticlinal walls (in the upper) and wavy anticlinal walls (in the lower), covered with a smooth cuticle, accompanied by anisocytic and anomocytic stomata. Non-glandular trichomes are present similar to those found on stem but more frequent. Idioblasts similar to those found in the stem and fragments of lignified xylem vessels, showing spiral or annular thickenings are present.

\section{The root (Figure 4)}

A transverse section in the root (figure $4 a$ ) is nearly circular in outline. It shows an outer zone of cork, followed by a narrow zone of phelloderm surrounding a wide vascular cylinder which is traversed by medullary rays. The cork (Figure 4b, c): It is formed of 3-4, radially arranged rows of tangentially elongated, polygonal cells with thin, brown suberized and partially lignified walls. The phelloderm: It consists of 6-8 rows of nearly polygonal, tangentially elongated, thin-walled parenchyma cells with narrow intercellular spaces. Idioblasts similar to those found in the stem are scattered.

The vascular system: The phloem is formed of soft tissues (phloem elements and phloem parenchyma). it shows scattered idioblasts similar to those of the phelloderm. The cambium is distinct, formed of 4-6 rows of thin walled radially elongated cambial cells. The xylem is formed of a continuous ring of lignified xylem elements. It consists of lignified xylem vessels with spiral and annular thickening, few lignified fibrotracheids with moderately thick pitted walls, comparatively wide lumen and obtuse ends, fragments of fusiform pitted lignified wood fibers with moderate thick walls.

The powder of the root (Figure 4c) is pale brownish in color, odorless with a slightly bitter taste. Microscopically, it is characterized by the presence of fragments of pale brownish, polygonal, thin suberized and partially lignified cork cells. Fragments of lignified xylem vessels of annular and spiral thickenings. Fragments of fusiform, pitted, lignified fibrotracheids with moderately thick-walled, comparatively wide lumina and obtuse ends, fragments of fusiform pitted lignified wood fibers with moderate thick-walled and narrow lumen and tapered ends, rectangular thin lignified wood parenchyma cells and idioblasts are shown in parenchymatous cells or scattered in the field.

Microscopical measurements of all plant organs are illustrated in Table 1.

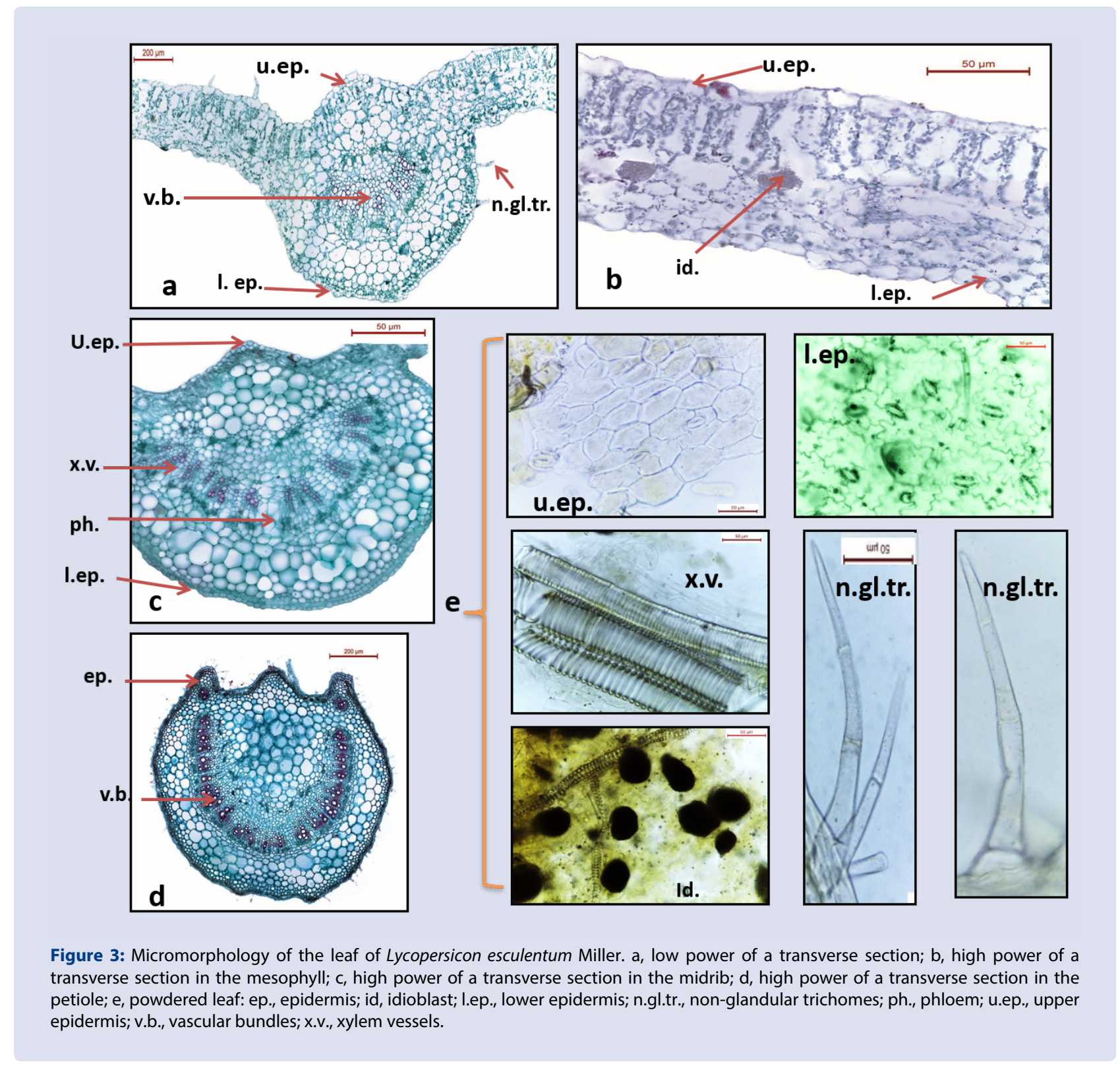




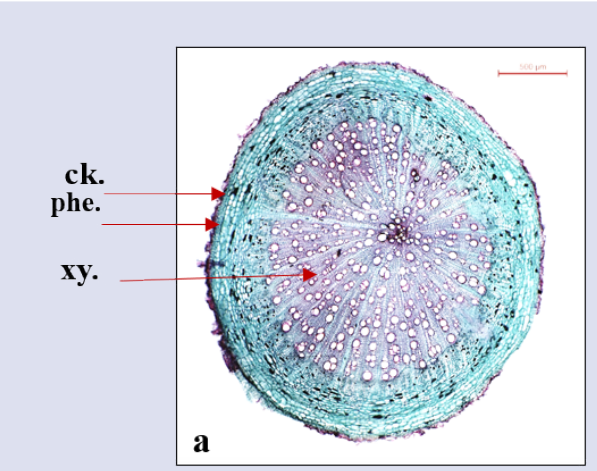

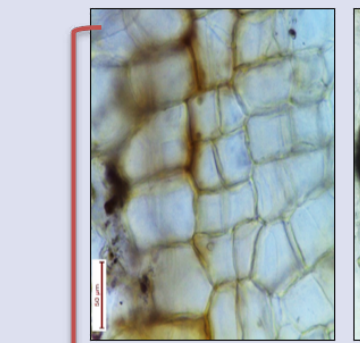

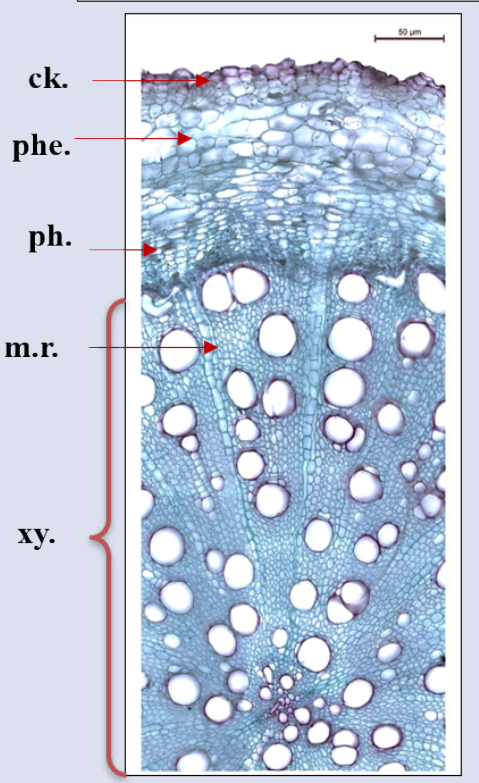

b ck.

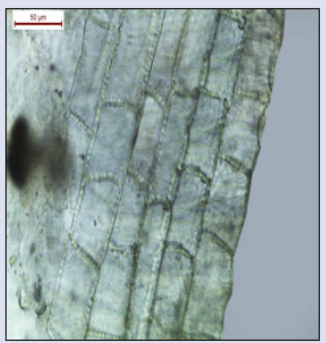

w.p.

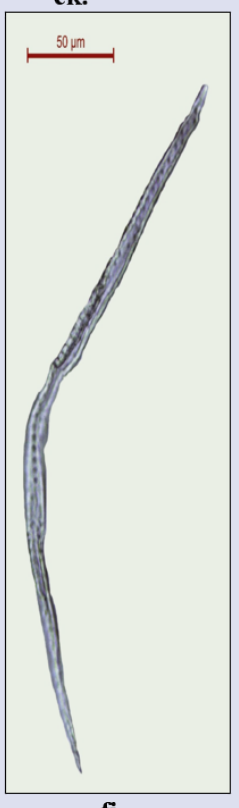

fi.

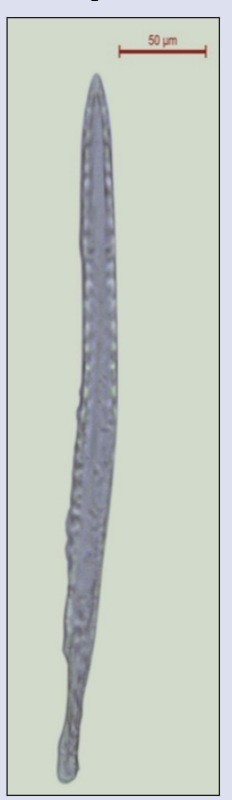

f.tr.

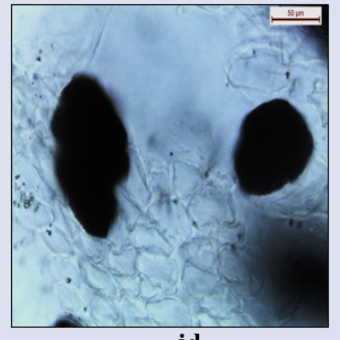

id.
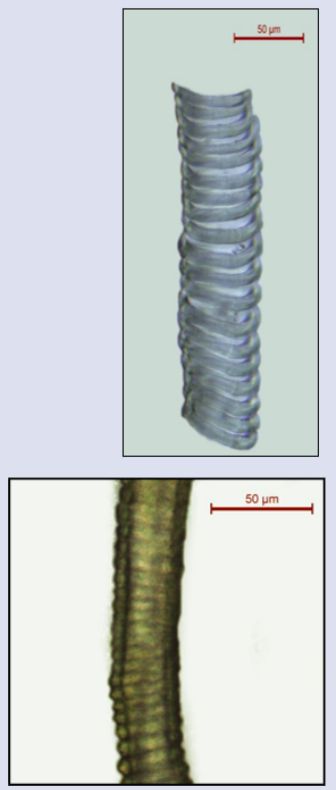

x.v.

Figure 4: Micromorphology of the root of Lycopersicon esculentum Miller. $a$, Low power of a transverse section; $b$, High power of transverse section of the stem; c, powdered root: ck. cork; fi, fiber; f.tr., fibrotrachieds; id., idioblasts; m.r., medullary rays; ph., phloem; x.v., xylem vessels; w.p., wood parenchyma.

Table 1: Microscopical measurements of the leaf, stem, and root of Lycopersicon esculentum Miller (in microns).

\begin{tabular}{|c|c|c|c|c|}
\hline Elements & Length & Width & Height & Diameter \\
\hline \multicolumn{5}{|l|}{ Leaf } \\
\hline Upper epidermal cells & $31-\underline{44}-45$ & $22-\underline{31}-36$ & $44-\underline{59}-72$ & - \\
\hline Lower epidermal cells & $44-\underline{54}-72$ & $22-\underline{27}-59$ & $44-\underline{68}-77$ & - \\
\hline Xylem vessels & - & - & - & $8-36-66$ \\
\hline Non glandular hair & $66-\underline{88}-250$ & $8-\underline{20}-22$ & - & - \\
\hline \multicolumn{5}{|l|}{ Stem } \\
\hline Epidermis & $\underline{38}-\underline{42}-50$ & $27-\underline{28}-50$ & $28-\underline{50}-55$ & - \\
\hline Xylem vessels & - & - & - & $57-\underline{85}-95$ \\
\hline Non glandular hair & $85-\underline{166}-222$ & $14-16-22$ & - & - \\
\hline Fiber & $300-\underline{330}-340$ & $7-\underline{11}-15$ & - & - \\
\hline \multicolumn{5}{|l|}{ Root } \\
\hline Cork cells & $22-\underline{45}-55$ & $9-\underline{25}-35$ & $9-\underline{50}-55$ & - \\
\hline Tracheidal fiber & $292-\underline{407-427}$ & $10-\underline{17}-21$ & - & - \\
\hline Xylem vessels & - & - & - & $22-\underline{55}-60$ \\
\hline Fiber & $387-\underline{429}-439$ & $4-\underline{8}-12$ & - & - \\
\hline
\end{tabular}




\section{Phytochemical Study}

\section{Preliminary phytochemical screening}

The results of preliminary phytochemical screening (Table 2) confirmed the presence of carbohydrates and/or glycosides, sterols and/ or triterpenes, alkaloids and /or nitrogenous compounds, flavonoids, tannins, cardiac glycosides and saponins in the leaf, stem and root.

\section{Total phenolics and flavonoids content}

The total phenolics content in the leaf, stem and root (Figure 5) were found to be $(84.29,50.94$ and $40.71 \mu \mathrm{g}) \mathrm{GAE} / \mu \mathrm{g}$ extract, and the total flavonoids content (Figure 6) was found to be (50.49, 9.10 and $1.32 \mu \mathrm{g}$ ) $\mathrm{QE} / \mathrm{mg}(0.1 \%)$ extract of leaf, stem and root, respectively.

\section{Results of successive extraction and fractionation}

The results of the percentage yields of the prepared extractives and their physicochemical examination recorded in Table 3 revealed that the percentage yield of the $70 \%$ ethanolic extractives of the leaf, stem and root were nearly similar (13.83\%, $13.79 \%$ and $12.1 \%$ respectively). Although, the amount of $n$-hexane, methylene chloride, ethyl acetate and $n$-butanol extractives were higher in the leaf than in other fractions of the stem and the root. The $n$-butanol fractions of the leaf, the stem

\begin{tabular}{lccc}
\hline Constituents & Leaf & Stem & Root \\
Carbohydrates andor glycosides & + & + & + \\
Sterols andor triterpenes & ++ & ++ & + \\
Flavonoids & ++ & ++ & \pm \\
Tannins & ++ & ++ & + \\
Alkaloids andor nitrogenous bases & ++ & ++ & ++ \\
Saponins & \pm & \pm & \pm
\end{tabular}

$(++)$ strongly positive (+) present, ( \pm ) slightly positive, (-) negative not detected.

Total Phenolics content

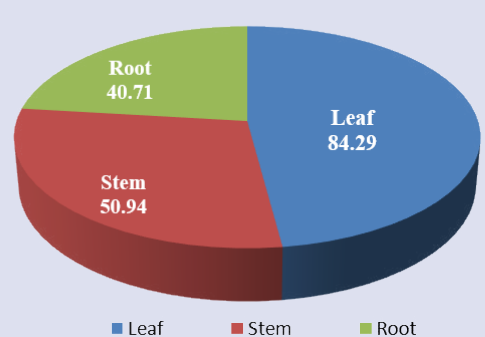

Total Flavonoids content

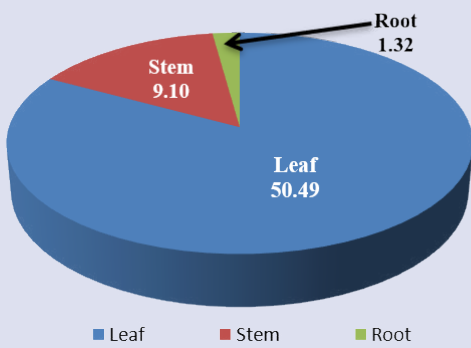

Figure 5: (A) Pie chart representing the total phenolics content in the leaf, stem and root and (B) Pie chart representing the total flavonoids content in the leaf stem and root.

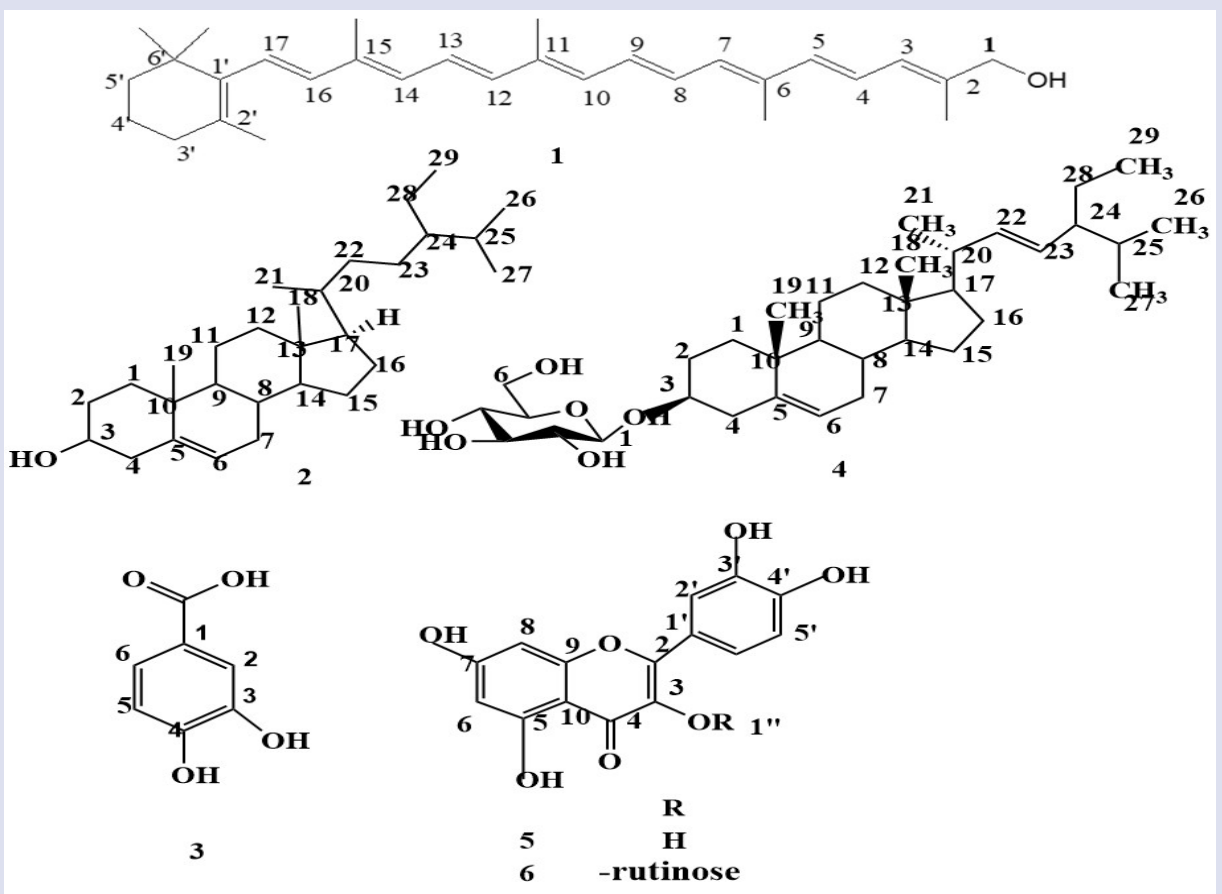

Figure 6: Structures of isolated compounds. 
Table 3: Percentage yields and results of the physicochemical examination of the different extractives of the leaf, stem, and root of Lycopersicon esculentum Miller.

\begin{tabular}{|c|c|c|c|c|c|c|c|c|c|c|c|c|c|c|c|}
\hline Extractives & Leaf & & & & & Stem & & & & & Root & & & & \\
\hline & $\begin{array}{l}\text { Weight } \\
\text { (g) }\end{array}$ & $\begin{array}{l}\text { \%Yield }{ }^{*} \\
w / w\end{array}$ & Color & Taste & $\begin{array}{l}\text { Detected } \\
\text { contituents }\end{array}$ & $\begin{array}{l}\text { Weight } \\
\text { (g) }\end{array}$ & $\begin{array}{l}\text { \%Yield } \\
\text { w/w }\end{array}$ & Color & Taste & $\begin{array}{l}\text { Detected } \\
\text { constituents }\end{array}$ & $\begin{array}{l}\text { Weight } \\
\text { (g) }\end{array}$ & $\begin{array}{l}\text { \%Yield }{ }^{*} \\
w / w\end{array}$ & Color & Taste & $\begin{array}{l}\text { Detected } \\
\text { contituents }\end{array}$ \\
\hline Ethanol 70\% & 156.3 & 13.83 & Dark green & $\begin{array}{l}\text { Bitter } \\
\text { astringe nt }\end{array}$ & $\begin{array}{l}\text {-S/tr } \\
\text {-Flav } \\
\text {-Tan } \\
\text {-Carb/gly } \\
\text {-Alka }\end{array}$ & 215.4 & 13.79 & $\begin{array}{l}\text { Dark } \\
\text { green }\end{array}$ & $\begin{array}{l}\text { Bitter } \\
\text { astringent }\end{array}$ & $\begin{array}{l}\text {-Strr } \\
\text {-Flav } \\
\text {-Tan } \\
\text {-Carb/gly } \\
\text {-Alka }\end{array}$ & 18.15 & 12.10 & $\begin{array}{l}\text { Dark } \\
\text { brown }\end{array}$ & $\begin{array}{l}\text { Bitter } \\
\text { astringent }\end{array}$ & $\begin{array}{l}\text {-S/tr } \\
\text {-Flav } \\
\text {-Tan } \\
\text {-Carb/gly } \\
\text {-Alka }\end{array}$ \\
\hline$n$-Hexane & 32 & 20.47 & Green & Bitter & - S/tr & 30.1 & 13.93 & Green & Bitter & $-S / \operatorname{tr}$ & 0.29 & 1.6 & $\begin{array}{l}\text { Faint } \\
\text { brown }\end{array}$ & Bitter & -S/tr \\
\hline $\begin{array}{l}\text { Methylene } \\
\text { chloride }\end{array}$ & 22.2 & 14.23 & $\begin{array}{l}\text { Yellowish } \\
\text { green }\end{array}$ & Bitter & $\begin{array}{l}\text {-S/tr } \\
\text {-Flav }\end{array}$ & 10.1 & 4.69 & $\begin{array}{l}\text { Yellowish } \\
\text { green }\end{array}$ & Bitter & $\begin{array}{l}-S \text { tr } \\
\text {-Flav }\end{array}$ & 0.37 & 2.03 & $\begin{array}{l}\text { Faint } \\
\text { green }\end{array}$ & Bitter & $\begin{array}{l}\text {-Str } \\
\text {-Flav }\end{array}$ \\
\hline Ethyl acetate & 14.3 & 9.15 & $\begin{array}{l}\text { Yellowish } \\
\text { green }\end{array}$ & Astringent & $\begin{array}{l}\text {-Flav } \\
\text {-Tan } \\
\text {-Carb/gly }\end{array}$ & 4.3 & 2.0 & $\begin{array}{l}\text { Yellowish } \\
\text { green }\end{array}$ & Astringent & $\begin{array}{l}\text {-Flav } \\
\text {-Tan } \\
\text {-Carb/gly }\end{array}$ & 0.35 & 1.93 & Brown & Astringent & $\begin{array}{l}\text {-Flav } \\
\text {-Tan } \\
\text {-Carb/gly }\end{array}$ \\
\hline $\begin{array}{l}n \text {-Butanol } \\
{ }^{*} \text { Calcul }\end{array}$ & $\begin{array}{l}50.3 \\
\text { ated on }\end{array}$ & $\begin{array}{l}32.18 \\
\text { dried } w\end{array}$ & $\begin{array}{l}\text { Dark } \\
\text { brown } \\
\text { eight, alka: }\end{array}$ & $\begin{array}{l}\text { Bitter } \\
\text { alkaloids; }\end{array}$ & $\begin{array}{l}\text {-Flav } \\
\text {-Carb/gly } \\
\text {-Alka } \\
\text { carb/gly: c }\end{array}$ & $\begin{array}{l}29.1 \\
\text { arbohyd }\end{array}$ & $\begin{array}{l}13.51 \\
\text { rates/or g }\end{array}$ & $\begin{array}{l}\text { Dark } \\
\text { brown } \\
\text { lycosides; }\end{array}$ & $\begin{array}{l}\text { Bitter } \\
\text { flav: flavo }\end{array}$ & $\begin{array}{l}\text {-Flav } \\
\text {-Carb/gly } \\
\text {-Alka } \\
\text { noids; str }\end{array}$ & $\begin{array}{l}1.22 \\
: \text { sterols }\end{array}$ & $\begin{array}{l}6.72 \\
\text { and/or } \\
\text { trite }\end{array}$ & $\begin{array}{l}\text { Dark } \\
\text { brown } \\
\text { rpenes; }\end{array}$ & $\begin{array}{l}\text { Bitter } \\
\text { tan: tannin }\end{array}$ & $\begin{array}{l}\text {-Flav } \\
\text {-Carb/gly } \\
\text {-Alka } \\
\text { s. }\end{array}$ \\
\hline
\end{tabular}

*Calculated on dried weight, alka: alkaloids; carb/gly: carbohydrates/or glycosides; flav: flavonoids; s/tr: sterols and/or triterpenes; tan: tannins.

and the root represented the highest yield of all extractives $(5.1 \%$, $2.68 \%$ and $2.95 \%$, respectively).

The following constituents were detected in the different extractives:

Sterols and/or triterpenes were detected in the ethanol 70\%, n-hexane and methylene chloride extractives. Carbohydrates andor glycosides were detected in the ethyl acetate and n-butanol extractives. Flavonoids and tannins were detected in the methylene chloride, ethyl acetate and n-butanol extractives. Alkaloids and/or nitrogenous compounds were detected in the n-butanol extractives.

\section{Isolation and characterization of isolated compounds}

The isolation was focused on the fractions of the leaf based on the high yield of the different fractions in the leaf in comparison to the stem and root, in addition to the high values of total phenolics and flavonoids content in the leaf. Six known compounds were isolated for the first time from the leaf and identified as apo- $\beta$-carotenol (1),,$^{23,24} \beta$-sitosterol $(2)^{25}$ from the $n$-hexane fraction, protocatechuic acid (3), stigmasterol 3 -O- $\beta$ - $D$-glucoside (4) ${ }^{26}$ from the ethyl acetate fraction in addition to quercetin (5) and rutin (6) ${ }^{27}$ from the $n$-butanol fraction. Chemical structural elucidation was confirmed by NMR, mass and comparison to the available literature data. Structures of all isolated compounds are illustrated in Figure 7.

\section{Spectroscopic data of isolated compounds}

\section{Apo- $\beta$-carotenol (1)}

Compound 1 exhibited a molecular weight of $419 \mathrm{~m} / \mathrm{z}$ indicated by electron impact Mass, corresponding to molecular formula $\mathrm{C}_{30} \mathrm{H}_{42} \mathrm{O}$. ${ }^{1} \mathrm{H}-\mathrm{NMR}\left(\mathrm{CDCl}_{3}, 400 \mathrm{MHz}\right) \delta: 1.62(19 \mathrm{H}, s, 5 \mathrm{Me}$ at H-2, 6, 11, 15, 2' and $4 \mathrm{H}$ at $4^{\prime}$ and $\left.5^{\prime}\right), 1.96-2.1\left(8 \mathrm{H}, s, 2 \mathrm{H}\right.$-at $3^{\prime}$ and $2 \mathrm{Me}$ at $\left.6^{\prime}\right), 4.14$ $(2 \mathrm{H}, d, J=8, \mathrm{H}-1), 12$ olefenic protons 5.1-5.4 H-3, 4, 5, 7, 8, 9, 10, 12, 13, 14, 16 and 17. ${ }^{13} \mathrm{C}-\mathrm{NMR}\left(\mathrm{CDCl}_{3}, 100 \mathrm{MHz}\right) \delta: 59.8(\mathrm{C}-1), 123.8-$ 140.1 all double bonds at C-2, C-3, C-4, C-5, C-6, C-7, C-8, C-9, C-10, C-11, C-12, C-13, C-14, C-15, C-16, C-17, C1' and C2', 16.4 (Me at C-2), 16.5 (Me at C-6), 16.7 (Me at C-2'), 18.1 (C-4'), 27.1 (C-3'), 27.1 (2 Me at C-6'), 40.0 (C-5'). The substitution position and assignment of ${ }^{13} \mathrm{C}$-NMR spectral data was confirmed by analysis of HSQC spectrum. The correlations of Me at H-2, 6, 11, 15, 2' and 4H / C-2, C-6, C-2', 2 Me at 6'/C-6' and olefinic protons/ double bonds. Based on the above spectral data and comparison to published data, ${ }^{23,24}$ compound $\mathbf{1}$ could be identified as apo- $\beta$-carotenol. For the best of our knowledge, this is the first report of the isolation of this apocarotenoid compound from the leaf, but it was previously reported in the fruit as a result of possible oxidation from carotenoids compounds. ${ }^{28}$

\section{$\beta$-sitosterol (2)}

White needle crystals, $(22 \mathrm{mg})$, m.p. $\left(135-137^{\circ} \mathrm{C}\right)$ soluble in $\mathrm{n}$-hexane and methylene chloride. It gives a violet color by spraying wit p-anisaldehyde reagent. ${ }^{1} \mathrm{H}-\mathrm{NMR}\left(\mathrm{CDCl}_{3}, 400 \mathrm{MHz}\right) \delta: 3.56(1 \mathrm{H}, \mathrm{m}$, H3), 5.36 (1H, m, H-6), 0.66 (s, 3H, H-18), 0.69 (d, 3H, H-26, J=7.12), 0.81 (d, 3H, H-27, J=8), 0.85(d, 3H, H-29, J=7.68), 0.92 (d, 3H, H-21, $\mathrm{J}=6.4), 1.01(\mathrm{~s}, 3 \mathrm{H}, \mathrm{H}-19) .{ }^{13} \mathrm{C}-\mathrm{NMR}\left(\mathrm{CDCl}_{3}, 100 \mathrm{MHz}\right) \delta: 137.3(\mathrm{C}-1)$, 31.9 (C-2), 71.8 (C-3), 42.3 (C-4), 140.8 (C-5), 121.7 (C-6), 31.6 (C-7), 50.2(C-9), 36.5 (C-10), 21.2 (C-11), 39.8 (C-12), 42.3 (C-13), 56.9 (C14), 26.1 (C-15), 28.3 (C-16), 56.1 (C-17), 36.2 (C-18), 19.1 (C-19), 34.0 (C-20), 25.4 (C-21), 45.8 (C-22), 23.1 (C-23), 12.3 (C-24), 29.2 (C-25), 19.8 (C-26), 19.4 (C-27), 19 (C-28), 12 (C-29). From the above finding and comparison with published data, ${ }^{25}$ compound 2 could be identified as $\beta$-sitosterol. This compound was the first time to be reported in the leaf, but it was previously identified in the seed and the fruit. ${ }^{25,29}$

\section{Protocatechuic acid (3)}

Yellow fine crystalline powder, m.p. (198-200 $\left.{ }^{\circ} \mathrm{C}\right)$, soluble in methanol. It gives blue color under UV that intensifies after spraying with ammonia and aluminum chloride reagent, in addition to green color with ferric chloride reagent indicating its phenolic acid nature. ${ }^{1} \mathrm{H}-\mathrm{NMR}$ (DMSO, $400 \mathrm{MHz}) \delta: 5.34(1 \mathrm{H}$, br.s. $), 6.81(1 \mathrm{H}, J=8 \mathrm{~Hz}, \mathrm{H}-5), 7.44(1 \mathrm{H}, J=10.4$ $\mathrm{Hz}, \mathrm{H}-6), 7.45$ (1H, $s, \mathrm{H}-2) .{ }^{13} \mathrm{C}-\mathrm{NMR}$ (DMSO, $\left.100 \mathrm{MHz}\right) \delta: 129.1$ (C1), 117.0 (C-2), 145.3 (C-3, 150.29 (C-4), 115.6 (C-5), 122.3 (C-6) and 168.2 (C-7). Based on the previous results and with comparison with published data, ${ }^{30}$ compound 3 was identified as protocatechuic acid. For the best of our knowledge, this compound is the first time to be reported in the leaf, but it was previously identified in the fruit through HPLC-ESI-QTOF analysis. ${ }^{31}$

\section{Stigmasterol-3-O- $\beta$-D-glucoside (4)}

White crystal, m.p. $280^{\circ} \mathrm{C}$, soluble in methylene chloride plus few drops of methanol. It gives a violet color by spraying wit $p$-anisaldehyde reagent. ${ }^{1} \mathrm{H}-\mathrm{NMR}$ (DMSO, $\left.400 \mathrm{MHz}\right) \delta: 0.66(3 \mathrm{H}, d, J=7.9 \mathrm{~Hz}, \mathrm{H}-21)$, $0.83(3 \mathrm{H}, d, J=6.4 \mathrm{~Hz}, \mathrm{H}-26), 1.01(3 \mathrm{H}, d, J=6.4 \mathrm{~Hz}, \mathrm{H}-27), 0.79(3 \mathrm{H}$, $t, J=6.3 \mathrm{~Hz}, \mathrm{H}-29), 0.90(3 \mathrm{H}, s, \mathrm{H}-18), 0.93(3 \mathrm{H}, s, \mathrm{H}-19), 4.21(1 \mathrm{H}$, $d, J=7.72 \mathrm{~Hz}, \mathrm{H}-23), 3.63(1 \mathrm{H}, \mathrm{m}, \mathrm{H}-3), 5.15(1 \mathrm{H}, \mathrm{dd}, J=15,8.4 \mathrm{~Hz}$, $\mathrm{H}-22), 5.33$ (1H, br.s, H-6). ${ }^{13} \mathrm{C}-\mathrm{NMR}$ (DMSO, $\left.100 \mathrm{MHz}\right) \delta: 29.7$ (C-2), 39.2 (C-7), 20.18 (C-11), 25.3 (C-15), 29.0 (C-16), 30.0 (C-25), 24.3 (C28), 31.9 (C-8), 37.3 (C-10), 38.8 (C-12), 36.7 (C-20), 42.3 (C-4), 50.1 (C-9), 40.3 (C-13), 40.5 (C-24), 42.2 (C-14), 55.8 (C-17), 141.1 (C-5), 121.9 (C-6), 138.2 (C-22), 129.3 (C23), 70.6 (C-2), 73.9 (C-3'), 61.6 (C$4), 77.4(\mathrm{C}-5)$ and 56.7 (C-6). From this data and by comparing with published data, ${ }^{26}$ compound 4 was identified as stigmasterol-3-O- $\beta$-D - 
glucoside. This compound was the first time to be reported in the leaf but its aglycone was previously identified in the seed and the fruit. ${ }^{25,29}$

\section{Quercetin (5)}

Yellow needle crystals, m.p. $\left(315-317^{\circ} \mathrm{C}\right)$, soluble in ethanol and DMSO. It gave yellow color in UV light intensified on exposure to ammonia vapor. $\lambda_{\max }(\mathrm{nm}),(\mathrm{MeOH}): 257,300 \mathrm{sh}, 359 ;(+\mathrm{NaOMe}): 272$, 327sh, 412; $\left(+\mathrm{AlCl}_{3}\right): 268,304 \mathrm{sh}, 396,428 ;\left(+\mathrm{AlCl}_{3} / \mathrm{HCl}\right): 267,300 \mathrm{sh}$, 367; (+NaOAc): 273sh, 387 and $\left(+\mathrm{NaOAc} / \mathrm{H}_{3} \mathrm{BO}_{3}\right) 265,300,387$. ${ }^{1} \mathrm{H}-\mathrm{NMR}\left(\mathrm{CD}_{3} \mathrm{OD}, 400 \mathrm{MHz}\right) \delta: 7.68(1 \mathrm{H}, d, J=1.8 \mathrm{~Hz}, \mathrm{H}-2$ '), $7.65(1 \mathrm{H}$, $\left.d d, J=8.48 \mathrm{~Hz}, \mathrm{H}-6^{\prime}\right), 6.88\left(1 \mathrm{H}, d, J=8.48 \mathrm{~Hz}, \mathrm{H}-5^{\prime}\right), 6.4(1 \mathrm{H}, d, J=1.48$ $\mathrm{Hz}, \mathrm{H}-8), 6.2(1 \mathrm{H}, d, J=1.64 \mathrm{~Hz}, \mathrm{H}-6)$. The UV spectral data showed a bathochromic shift in band $\mathrm{I}(\Delta \lambda \approx 38 \mathrm{~nm})$ on $\mathrm{NaOMe}$ addition as well as increase in intensity indicating a free $\mathrm{OH}$ group at $\mathrm{C} 4$ ". Fast decomposition takes place with $\mathrm{NaOMe}$ which can be monitored by a rapid decrease in intensity of band I detected by rerunning the spectrum indicating the presence of 3, 3", 4" hydroxyl groups. A bathochromic shift in band $\Pi(\Delta \lambda \approx 12 \mathrm{~nm})$ on addition of $\mathrm{NaOAc}$. Indicating free $\mathrm{OH}$ group at position 7. A hypochromic shift in band I after addition of $\mathrm{HCl}$ as well as bathochromic shift in band I with boric acid confirmed the presence of ortho dihydroxy groups. From the above data, and comparison to published data, compound $\mathbf{5}$ was identified as quercetin. It was the first time to be reported in the leaf but it was previously isolated from the seeds. ${ }^{32}$

\section{Rutin (6)}

Yellow needle crystals, m.p. $\left(192-195{ }^{\circ} \mathrm{C}\right)$, soluble in methanol. It gave yellow color in visible light, turned into brown under UV after treatment with ammonia vapors and aluminum chloride reagent. $\lambda_{\max }$ (nm), (MeOH): 257, 300sh, 359; (+NaOMe): 272, 327sh, 412; $\left(+\mathrm{AlCl}_{3}\right)$ : 268, 304sh, 396, 428; (+ $\left.\mathrm{AlCl}_{3} / \mathrm{HCl}\right): 267,300 \mathrm{sh}, 367 ;(+\mathrm{NaOAc}): 273 \mathrm{sh}$, 387 and $\left(+\mathrm{NaOAc} / \mathrm{H}_{3} \mathrm{BO}_{3}\right) 265,300,387 .{ }^{1} \mathrm{H}-\mathrm{NMR}\left(\mathrm{CD}_{3} \mathrm{OD}, 400 \mathrm{MHz}\right)$ $\delta: 6.4(1 \mathrm{H}, d, J=1.48 \mathrm{~Hz}, \mathrm{H}-6), 6.2(1 \mathrm{H}, d, J=1.64 \mathrm{~Hz}, \mathrm{H}-8), 6.8(1 \mathrm{H}$, $\left.d, J=8.32 \mathrm{~Hz}, \mathrm{H}-5^{\prime}\right), 7.68(1 \mathrm{H}, d, J=1.92 \mathrm{~Hz}, \mathrm{H}-2), 7.64(1 \mathrm{H}, d d, J$ $\left.=8.48,2 \mathrm{~Hz}, \mathrm{H}-6^{\prime}\right)$. Sugar (Glucose \& Rhamnose): 3.33-3.80 (sugar protons), $5.13\left(d, J=7.52 \mathrm{~Hz}, \mathrm{H}-1^{\prime \prime}\right), 4.5\left(1 \mathrm{H}, \mathrm{H}-1^{\prime \prime \prime}\right), 1.14\left(d, 3 \mathrm{H}, \mathrm{H}-6^{\prime \prime \prime}\right.$ , J=6.2, CH3). ${ }^{13} \mathrm{C}-\mathrm{NMR}\left(\mathrm{CD}_{3} \mathrm{OD}, 100 \mathrm{MHz}\right) 16.5$ (C-6"')), 68.3 (C-6"), 68.3 (C5"'), 70.0 (C-3'"'), 70.8 (C-2"''), 70.7 (C-4"), 74.3 (C-4"'), 75.8 (C-2"), 76.8 (C-5"), 67.1 (C-3"), 93.5 (C-8), 98.6 (C-6), 103.3 (C-1"'), 104.2 (C-1"'), 101.0 (C-10),114.6 (C-2'), $116.3\left(\mathrm{C}-5^{\prime}\right), 21.7\left(\mathrm{C}-1^{\prime}\right), 122.1$ (C-6'), 134.2 (C-3), 44.5 (C-3'), 148.4 (C-4'), 157.1 (C-9), 157.9 (C-2), 161.6 (C-5),164.7 (C-7), 178.0 (C-4). The UV spectrum of compound 6 in methanol revealed two major absorption bands at 257-359 nm, which indicated the presence of flavonol nucleus. Bathochromic shift with sodium methoxide supported the presence of hydroxyl groups in both rings A \& B. Sodium acetate bathochromic shift indicated the 7-hydroxy groups. The $\mathrm{AlCl}_{3}$ and $\mathrm{AlCl}_{3} / \mathrm{HCl}$ spectrum showed 5-hydroxy in ring A and ortho-dihydroxy groups in ring $\mathrm{B}$. the fact indicated that the 3-hydroxy group was absent or substituted. Based on the previous discussion and by comparison with published data, ${ }^{33}$ compound 6 was identified as quercetin-3-O-rutinoside (Rutin). It was previously isolated from the seeds ${ }^{34}$ and from the leaf. ${ }^{11}$

\section{CONCLUSION}

The current pharmacognostical study of Lycopersicon esculentum Miller cultivated in Egypt was investigated for the first time. The obtained results including the macro- and micromorphological features, preliminary phytochemical screening, successive extraction and the physicochemical examination of the different extractives, total phenolics and flavonoids content of the plant organs (leaf, stem and root) which could provide an authenticated data base for this Lycopersicon species. Based on the high yield of the different fractions in the leaf in comparison to the stem and root, in addition to the high values of total phenolics and flavonoids content in the leaf, the ethanolic extract of the leaf and its fractions were subjected to different chromatographic techniques resulting in isolation of six compounds for the first time from the leaf: apo- $\beta$-carotenol (1), $\beta$-sitosterol (2) from the $n$-hexane fraction, protocatechuic acid (3), stigmasterol 3 -O- $\beta$ - $D$-glucoside (4) from the ethyl acetate fraction in addition to quercetin (5) and rutin (6) from the $n$-butanol fraction.

\section{DEDICATION}

This paper is dedicated to the memory of our wonderful professor. Dr. Marawan M. Shabana, who sadly passed away in 2017.

\section{DECLARATIONS}

\section{Author contribution}

MMS, and FIF planned and designed the experiments. HAM performed the extraction procedure and isolation of compounds. HAM and MMS collaborated with the interpretation of the botanical profile and compounds identification. FIF and MMS collaborated with the preparation of the manuscript and critical analyses of the text. All authors approved the manuscript.

\section{Conflicts of interest}

The authors declare that they have no conflict of interest.

\section{REFERENCES}

1. Hunziker AT. South American Solanaceae: a synoptic survey. Linn Soc Symp Ser. Published online 1979.

2. Kalloo G. Genetic Improvement of Tomato. Springer Berlin Heidelberg; 1991.

3. Agrawal S, Rao AV. Tomato lycopene and its role in human health and chronic diseases. Cmaj. 2000;163(6):739-744.

4. Persia M, Parsons $C$, Schang M, Azcona J. Nutritional evaluation of dried tomato seeds. Poult Sci. 2003;82(1):141-146. doi:10.1093/ ps/82.1.141

5. Fernández-Ruiz V, Olives Al, Cámara M, Sánchez-Mata MDC, Torija ME. Mineral and trace elements content in 30 accessions of tomato fruits (Solanum lycopersicum L.,) and wild relatives (Solanum pimpinellifolium L., Solanum cheesmaniae L. Riley, and Solanum habrochaites S. Knapp \& D.M. Spooner). Biol Trace Elem Res. 2011;141(1-3):329-339. doi:10.1007/s12011-010-8738-6

6. Perveen R, Suleria HAR, Anjum FM, Butt MS, Pasha I, Ahmad S. Tomato (Solanum Iycopersicum) Carotenoids and Lycopenes Chemistry; Metabolism, Absorption, Nutrition, and Allied Health Claims-A Comprehensive Review. Crit Rev Food Sci Nutr. 2015;55(7):919-929. doi:10.1080/10408398.2012.657809

7. Burns J, Fraser PD, Bramley PM. Identification and quantification of carotenoids, tocopherols and chlorophylls in commonly consumed fruits and vegetables. Phytochemistry. 2003;62(6):939-947. doi:10.1016/S0031-9422(02)00710-0

8. Cataldi TRI, Lelario F, Bufo SA. Analysis of tomato glycoalkaloids by liquid chromatography coupled with electrospray ionization tandem mass spectrometry. Rapid Commun Mass Spectrom. 2005;19(21):3103-3110. doi:10.1002/rcm.2176

9. lijima $Y$, Watanabe B, Sasaki R, et al. Steroidal glycoalkaloid profiling and structures of glycoalkaloids in wild tomato fruit. Phytochemistry. 2013;95(June 2015):145-157. doi:10.1016/j.phytochem.2013.07.016

10. Nagaoka T, Yoshihara T, Ohra J, Sakamura S. Steroidal alkaloids from roots of tomato stock. Phytochemistry. 1993;34(4):1153-1157. doi:10.1016/S0031-9422(00)90734-9

11. Taveira M, Ferreres F, Gil-Izquierdo A, Oliveira L, Valentão P, Andrade PB. Fast determination of bioactive compounds from Lycopersicon esculentum Mill. leaves. Food Chem. 2012;135(2):748-755. doi:10.1016/j.foodchem.2012.05.016 
12. Yahara S, Uda N, Nohara T. Lycoperosides A-C, three stereoisomeric 23-acetoxyspirosolan-3ß-ol $\beta$-lycotetraosides from Lycopersicon esculentum. Phytochemistry. 1996;42(1):169-172. doi:10.1016/00319422(95)00854-3

13. Silva-Beltrán NP, Ruiz-Cruz $\mathrm{S}$, Chaidez $\mathrm{C}$, et al. Chemical constitution and effect of extracts of tomato plants byproducts on the enteric viral surrogates. Int J Environ Health Res. 2015;25(3):299-311. doi:1 $0.1080 / 09603123.2014 .938030$

14. Karimi E, Jaafar HZE, Ahmad S. Phytochemical analysis and antimicrobial activities of methanolic extracts of leaf, stem and root from different varieties of labisa pumila benth. Molecules. 2011;16(6):4438-4450. doi:10.3390/molecules16064438

15. Arab M, Bahramian B, Schindeler A, Valtchev P, Dehghani $F$ McConchie R. Extraction of phytochemicals from tomato leaf waste using subcritical carbon dioxide. Innov Food Sci Emerg Technol. 2019;57:102204. doi:10.1016/j.ifset.2019.102204

16. Shams-El-Din $\mathrm{MH}$; Abdel-Kader MM. Chemical and biological evaluation of tomato processing wastes. Egypt J Food Sci. 1997;25(1):151-162. Accessed December 11, 2019. http://agris.fao. org/agris-search/search.do?recordID=EG2001000123

17. Rizk EM, Bedier SH, Manal AEG. Utilization of Carotenoid Pigments Extracted From Tomato Peel As Natural Antioxidants and Colorants in Sunflower Oil and Spaghetti. Egypt J Agric Res. 2014;92(1):309-321.

18. El-Malah MH, Hassanein MMM, Areif MH, Al-Amrousi EF. Utilization of Egyptian Tomato waste as a potential source of natural antioxidants using solvents, microwave and ultrasound extraction methods. Am J Food Technol. 2015;10(1):14-25. doi:10.3923/ ajtt.2015.14.25

19. Abd El-Sattar A, El-Bana M. Utilization of Tomato Industry ByProducts in Production of Pan Bread. J Food Dairy Sci. 2016;7(3):201206. doi:10.21608/jfds.2016.42964

20. Kaur GJ, Arora DS. Antibacterial and phytochemical screening of Anethum graveolens, Foeniculum vulgare and Trachyspermum ammi. BMC Complement Altern Med. 2009;9(1):1-10. doi:10.1186/1472-6882-9-30

21. Djeridane A, Yousfi M, Nadjemi B, Boutassouna D, Stocker P, Vidal $\mathrm{N}$. Antioxidant activity of some algerian medicinal plants extracts containing phenolic compounds. Food Chem. 2006;97(4):654-660. doi:10.1016/j.foodchem.2005.04.028

22. Quettier-Deleu C, Gressier B, Vasseur J, et al. Phenolic compounds and antioxidant activities of buckwheat (Fagopyrum esculentum Moench) hulls and flour. J Ethnopharmacol. 2000;72(1-2):35-42. doi:10.1016/S0378-8741(00)00196-3

23. Tanaka $Y$, Inoue $T$, Okamoto $H, H a$ BS. The Occurrence of Apocarotenoids in the Sea Hare Dolabella auricularia. Nippon Suisan Gakkaishi (Japanese Ed. 1991;57(2):277-279. doi:10.2331/ suisan. 57.277
24. Yamashita E, Maruyama $Y$, Katsuyama M, Tsushima M, Arai $\mathrm{S}$, Matsuno T. The Presence and Origin of an Apocarotenoid, Galloxanthin in Ayu Plecoglossus altivelis. Fish Sci. 1998;64(5):826830. doi:10.2331/fishsci.64.826

25. Whitaker BD. Changes in lipids of tomato fruit stored at chilling and non-chilling temperatures. Phytochemistry. 1991;30(3):757-761. doi:10.1016/0031-9422(91)85247-W

26. Alam MS, Chopra N, Ali M, Niwa M. Oleanen and stigmasterol derivatives from Ambroma Augusta. Phytochemistry. 1996;41 (4):1197-1200. doi:10.1016/0031-9422(95)00774-1

27. Mabry, J.T.; Markham, K.R. and Thomas MB. "The Systemic Identification of Flavonoids", 2nd edition, Springer-verlag, New York, (1970). - Google Search.

28. Ilg A, Bruno M, Beyer P, Al-Babili S. Tomato carotenoid cleavage dioxygenases $1 \mathrm{~A}$ and 1B: Relaxed double bond specificity leads to a plenitude of dialdehydes, mono-apocarotenoids and isoprenoid volatiles. FEBS Open Bio. 2014;4:584-593. doi:10.1016/j. fob.2014.06.005

29. Liao $P$, Chen $X$, Wang $M$, Bach TJ, Chye ML. Improved fruit $\alpha$-tocopherol, carotenoid, squalene and phytosterol contents through manipulation of Brassica juncea 3-HYDROXY-3METHYLGLUTARYL-COA SYNTHASE1 in transgenic tomato. Plant Biotechnol J. 2018;16(3):784-796. doi:10.1111/pbi.12828

30. Ayinde BA, Onwukaeme DN, Omogbai EK. Isolation and characterization of two phenolic compounds from the stem bark of Musanga cecropioides R. brown (Moraceae). Acta Pol Pharm - Drug Res. 2007;64(2):183-185.

31. Vallverdú-Queralt $A$, Jáuregui $O$, Di Lecce $G$, Andrés-Lacueva $C$, Lamuela-Raventós RM. Screening of the polyphenol content of tomato-based products through accurate-mass spectrometry (HPLC-ESI-QTOF). Food Chem. 2011;129(3):877-883. doi:10.1016/j. foodchem.2011.05.038

32. Torres CA, Davies NM, Yañez JA, Andrews PK. Disposition of selected flavonoids in fruit tissues of various tomato (Lycopersicon esculentum Mill.) genotypes. J Agric Food Chem. 2005;53(24):95369543. doi:10.1021/jf051176t

33. Mabry T, Markham KR, Thomas MB. The Ultraviolet Spectra of Flavones and Flavonols. Syst Identif Flavonoids SE - 5. 1970; (see 111):41-164. doi:10.1007/978-3-642-88458-0_5

34. Ferreres F, Taveira M, Pereira DM, Valentão P, Andrade PB. Tomato (Lycopersicon esculentum) seeds: New flavonols and cytotoxic effect. J Agric Food Chem. 2010;58(5):2854-2861. doi:10.1021/ jf904015f 


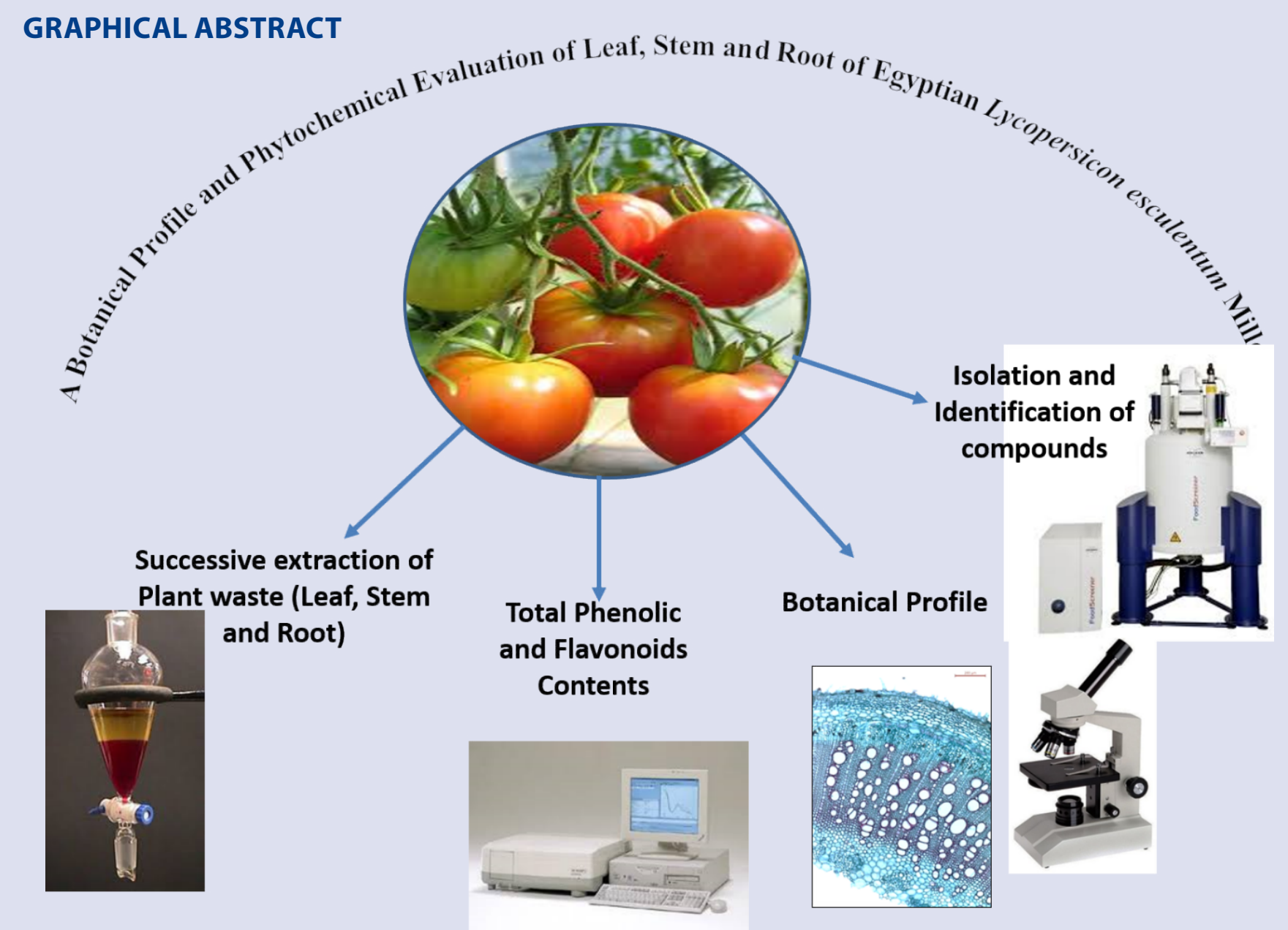

Cite this article: Fathy FI, Shabana MM, Mansour HA, Sabry MM. A Botanical Profile and Phytochemical Evaluation of Leaf, Stem and Root of Egyptian Lycopersicon esculentum Miller. Pharmacogn J. 2021;13(4): 1019-1029. 